\title{
PENYELESAIAN KREDIT MACET DENGAN AGUNAN YANG \\ DIAMBIL ALIH (AYDA) SEBAGAI UPAYA PERLINDUNGAN KREDITUR DI PERSEROAN DAERAH BPR BANK KLATEN
}

\author{
Bayu Rangga Warsito \\ E-mail: bayuranggaja@gmail.com \\ Mahasiswa Fakultas Hukum Universitas Sebelas Maret Surakarta \\ Albertus Sentot Sudarwanto \\ E-mail: alsentotsudarwanto@yahoo.com \\ Dosen Fakultas Hukum Universitas Sebelas Maret Surakarta
}

\begin{abstract}
This article was aimed to find out the resolution of bad credits with Collateral procedures are taken over (AYDA) at the Regional Company BPR Bank Klaten the effort against the debtor as one lender protection efforts. This research is a study of empirical law that is descriptive to describe. Data collection techniques are conducted with interviews, observations or observations literature studies. Based on the results of the research and the discussion produced drawing a conclusion. First, the settlement of bad credit at the Regional Company BPR Bank Klaten with the debtor sent by the provision of a warning letter for three times, then do the call in written and spoken, then do negosiation to turn over as collateral by AYDA perform procedure. Second, the impediments that experienced by the Regional Company BPR Bank Klaten in the face of non-perfoming loans that is a lack of idea of being careful with a field officer, the existence of faith not good from a debtor, and the existence of the disasters which hit a debtor. While from the regulation those are many requirements in notarial required in AYDA, and the term of selling collateral maximum one year.
\end{abstract}

Keywords: Settlement Of Bad Credit; AYDA; The Protection Of Creditors; The Company Of The Rural Banks.

\begin{abstract}
Abstrak
Artikel ini bertujuan untuk mengetahui penyelesaian kredit macet dengan prosedur Agunan yang diambil alih (AYDA) pada Bank Perkreditan Rakyat Klaten terhadap debitur sebagai salah satu upaya perlindungan kreditur. Penelitian hukum ini merupakan penelititan hukum empiris yang bersifat deskriptif. Teknik pengumpulan data yang digunakan yaitu wawancara narasumber dan studi kepustakaan. Berdasarkan hasil penelitian dan pembahasan, dihasilkan simpulan. Kesatu, penyelesaian kredit macet pada BPR Klaten dengan debitur dilakukan dengan pemberian Surat Peringatan hingga tiga kali, kemudian melakukan pemanggilan secara lisan dan tertulis, kemudian negosiasi untuk menyerahkan agunan dengan melaksanakan prosedur AYDA. Kedua, hambatan yang dialami oleh BPR Klaten dalam menghadapi kredit macet yaitu kurangnya ketelitian petugas lapangan, adanya itikad tidak baik dari debitur, dan adanya musibah yang menimpa debitur. Sedangkan dari regulasi, hambatan yang ada yaitu banyaknya persyaratan secara Notarial yang dibutuhkan dalam AYDA, dan jangka waktu penjualan yang terlalu cepat yaitu maksimal satu tahun.
\end{abstract}

Kata Kunci: Penyelesaian Kredit Macet; AYDA; Perlindungan Kreditur; Perseroan Daerah BPR Bank Klaten. 


\section{A. Pendahuluan}

Perbankan merupakan salah satu lembaga keuangan yang memiliki peranan penting dalam pembangunan perekonomian nasional. Keberadaan Bank sebagai lembaga intermediasi, Mathias Dewatripont dan Jean Tirole mengatakan bahwa "a Bank is a financial intermediary that participates in the payment system and finance entities in financial deficit (typically the public sector, non financial firm, and some household) using the finds of entities in financial surplus (typically households)" (Mathias Dewatripont dan Jean Tirole, The Prudential Regulation of Banks, Editions Payout Lausanne, Switzerland, 1993,h. 13)

Upaya yang dilakukan pemerintah untuk mewujudkan kesejahteraan masyarakat yang adil dan makmur haruslah diiringi dengan peran dari masyarakat itu sendiri. Seiring dengan meningkatnya kebutuhan masyarakat dalam kegiatan pembangunan khususnya di bidang perekonomian maka meningkat pula kebutuhan terhadap pendanaan. Yang sebagian besar dana yang diperlukan untuk memenuhi kebutuhan tersebut diperoleh melalui kegiatan pinjam meminjam (Purwahid Patrik, 2005: 33). Dalam melaksanakan kegiatan usahanya sebagaimana tersebut diatas maka Bank harus berpedoman kepada perangkat hukum yang terkait, antara lain Undang-Undang Nomor 7 Tahun 1992 sebagaimana diubah dengan Undang-Undang Nomor 10 Tahun 1998 tentang Perbankan. Salah satu ketentuan yang berkaitan dengan kegiatan pinjam meminjam ini adalah Pasal 8 Ayat (1) Undang-Undang Perbankan yaitu mengenai peminjaman kredit.

Bank sebagai penyalur dan penyedia dana kredit bagi masyarakat tidak selalu berjalan lancar, ada kalanya debitur tidak memenuhi kewajiban sesuai waktu yang disepakati (wanprestasi). Wanprestasi dianggap sebagai suatu kegagalan untuk melaksanakan janji yang telah disepakati disebabkan debitor tidak melaksanakan kewajiban tanpa alasan yang dapat diterima oleh hukum apabila terjadi wanprestasi, kreditur dapat menuntut ganti rugi dan pembatalan. Ketentuan ganti rugi yang mengatur tentang perikatan-perikatan untuk memberikan sesuatu, tercantum dalam Pasal 1236 Kitab Undang-Undang Hukum Perdata. yang berbunyi "Si berhutang adalah berwajib memberikan ganti biaya, rugi, dan bunga kepada si berpiutang, apabila ia telah membawa dirinya dalam keadaan tidak mampu untuk menyerahkan kebendaannya, atau telah tidak merawat sepatutnya guna menyelamatkannya". Sedangkan Pasal 1239 Kitab Undang-Undang Hukum Perdata mengatur tentang perikatanperikatan untuk berbuat sesuatu atau untuk tidak berbuat sesuatu, yang menetapkan bahwa "Tiap-tiap perikatan untuk bertindak sesuatu, atau untuk tidak berbuat sesuatu, apabila si berutang tidak memenuhi kewajibannya, mendapatkan penyelesaiannya dalam kewajiaban memberikan pengganti biaya, rugi dan bunga". Maka dari itu, Bank mensyaratkan adanya agunan atau jaminan bagi para debitur yang tidak mampu membayar atau melunasi kreditnya.

Untuk mengatasi peliknya eksekusi atas jaminan tersebut adalah dengan cara melakukan alternatif penyelesaian kredit macet. Salah satu bentuk penyelesaian kredit macet yang dilakukan oleh Bank adalah melalui pengambilalihan asset/jaminan milik debitur atau lebih dikenal dengan istilah Agunan Yang Diambil Alih (selanjutnya disebut sebagai AYDA). Praktek pelaksanaan AYDA dilakukan karena terdapatnya berbagai hambatan atau kendala dalam pelaksanaan eksekusi hak tanggungan yang merugikan pihak Bank sebagai kreditur serta salah satu upaya jangka pendek Bank untuk mengatasi tingginya jumlah kredit macet yang berpengaruh besar terhadap kelangsungan usaha Bank itu sendiri. 
Mengenai kasus AYDA di Perseroda BPR Bank Klaten sendiri yang terjadi pada suatu perjanjian kredit, dimana nasabah (debitur) memberikan agunan berupa tanah dan bangunan di daerah Joyotakan. Ketika jatuh tempo debitur tidak bisa membayar jumlah kredit yang sudah ditentukan pada perjanjian, dalam artian debitur wanprestasi. Setelah itu pihak debitur dengan itikad baik memberikan agunannya kepada kreditur. Namun ketika kreditur menggunakan penyelesian kredit macet dengan AYDA dimana memerlukan tanda tangan pihak debitur dan kreditur pada akta jual beli menemukan hambatan. Pihak debitur setelah Surat Peringatan tidak bisa dihubungi sehingga tidak langsung memberi tandatangan. Oleh karena itu pihak kreditur harus bisa melakukan negosiasi dan mencari car agar pihak debitur tadi bisa memberikan tandatangan untuk dilakukannya AYDA, problematika itulah yang dibahas dalam artikel ini.

\section{B. Metode Penelitian}

Penulis menggunakan jenis penelitian hukum empiris. Dalam hal ini, sifat empiris ditunjukkan dengan penelitian terhadap data primer dari wawancara narasumber terkait dan data sekunder yaitu dari literatur hukum dan perundang-undangan. Sifat dari penelitian ini adalah deskriptif, yaitu memberi data seteliti mungkin tentang manusia, keadaan atau gejalagejala lainnya dengan cara mengumpulkan data, menyusun, mengklarifikasi, menganalisis, dan menginterprestasikannya (Soerjono Soekanto, $2010: 10$ ). Sumber data yang digunakan Penulis dalam penelitian ini adalah data primer dan sekunder yang selanjutnya dilakukan analisis secara kualitatif.

\section{Hasil Penelitian dan Pembahasan}

Sejarah Perseroan Daerah BPR Bank Klaten tidak dapat dipisahkan dari hari jadi Pemerintah Kabupaten Klaten atas pelantikan anggota Legislatif DPRDS Kabupaten Klaten sebagai pengganti Badan Perwakilan Rakyat pada 28 Oktober 1950 maka resmilah berdirinya Pemerintah Daerah Otonom. Setelah pemerintah Kabupaten Klaten berdiri, maka sejak tanggal 1 Agustus 1951 dibuatlah Peraturan Daerah (Perda) Kabupaten Klaten tentang Pendirian Bank Pasar yaitu Perda Nomor 12/Per/DPRD/1951. Sebagai pelaksana dari pada Peraturan Daerah tersebut dibuatlah Anggaran Dasar dan Anggaran Rumah Tangga Bank Pasar yang ditetapkan dengan Surat Keputusan tanggal 22 November 1951 Nomor 5/SK/1951. Seriring berjalannya waktu serta dalam rangka menghadapi perekonomi yang bergerak cepat, dan kompetitif dengan tingkat tantangan yang semakin kompleks maka dengan Peraturan Daerah Kabupaten Klaten Nomor 6 Tahun 2010 pada Bab II Pasal 2 Perusahaan Daerah Bank Perkreditan Bank Pasar kabupaten Klaten diganti namanya menjadi PD BPR Bank Klaten. Berkedudukan di Ibu Kota Kabupaten Klaten dan membuka kantor Cabang, Kantor Kas, atau Unit-Unit pelayanan sesuai dengan ketentuan yang berlaku.

Dalam Pasal 1 Butir 1 Undang-Undang No. 10 Tahun 1998 atas perubahan UndangUndang No.7 tahun 1992 tentang Perbankan dirumuskan bahwa Perbankan adalah segala sesuatu yang menyangkut tentang Bank, mencakup kelembagaan, kegiatan usaha, serta cara dan proses dalam melaksanakan kegiatan usahanya. Berdasarkan definisi perbankan tersebut, fungsi dari Bank dapat dikelompokan menjadi tiga, yaitu Bank sebagai lembaga yang menghimpun dana-dana masyarakat atau penerima kredit, Bank sebagai lembaga yang 
menyalurkan dana dari masyarakat dalam bentuk kredit atau sebagai lembaga pemberi kredit, dan Bank sebagai lembaga yang melancarkan transaksi perdagangan dan pembayaran utang.

Kredit menurut Undang-Undang No. 10 Tahun 1998 tentang Perbankan memberikan definisi "Penyediaan uang atau tagihan yang dapat dipersamakan dengan itu, berdasarkan persetujuan atau kesepakatan pinjam-meminjam antara Bank dengan pihak lain yang mewajibkan pihak peminjam untuk melunasi utangnya setelah jangka waktu tertentu dengan pemberian bunga". Selanjutnya merujuk kepada Peraturan Bank Indonesia No.14/15/ PBI/2012 tentang Penilaian Kualitas Aset Bank Umum, kredit adalah penyediaan uang atau tagihan yang dapat dipersamakan dengan itu berdasarkan persetujuan atau kesepakatan pinjam-meminjam antara Bank dengan pihak lain yang mewajibkan pihak peminjam untuk melunasi utangnya setelah jangka waktu tertentu dengan pemberian bunga termasuk: cerukan (overdraft), yaitu saldo negatif pada rekening giro nasabah yang tidak dapat dibayar lunas pada akhir hari; pengambilalihan tagihan dalam rangka kegiatanan piutang; dan pengambilalihan atau pembelian kredit dari pihak lain.

Pada prakteknya, kreditur sering mengalami kredit macet yang disebabkan oleh berbagai faktor. Kredit macet atau nonperforming loan merupakan resiko yang dimana terdapat dalam setiap pemberian kredit oleh Bank.Resiko tersebut berupa keadaan dimana kredit tidak kembali tepat pada waktunya. Kredit bermasalah atau non performing loan dalam perbankan dapat disebabkan oleh berbagai faktor, misalnya saja ada kesengajaan dari pihak-pihak yang terlibat dalam proses kredit, kesalahan prosedur dalam pemberian kredit, atau disebabkan oleh faktor lain seperti faktor makro ekonomi (Jamal Wiwoho, 2014 : 100). Apabila kredit macet tersebut terjadi karena debitur tidak melaksanakan prestasinya sebagaimana terdapat dalam perjanjian kredit, maka sebelum kreditur melakukan eksekusi barang jaminan, debitur harus terlebih dahulu dinyatakan wanprestasi, yang dilakukan melalui putusan pengadilan. Untuk itu kreditur harus menggugat debitur atas dasar wanprestasi. Akan tetapi sebelum menggugat debitur, kreditur harus melakukan somasi terlebih dahulu yang isinya agar debitur memenuhi prestasinya. Apabila debitur tidak juga memenuhi prestasinya, maka kreditur dapat menggugat debitur atas dasar wanpretasi, dengan mana apabila pengadilan memutuskan bahwa debitur telah wanprestasi, maka kreditur dapat melakukan eksekusi atas barang jaminan yang diberikan oleh debitur (J. Satrio, 2002 : 78-81).

Solusi yang dapat dilakukan adalah dengan melakukan penyitaan jaminan dengan prosedur agunan yang diambil alih (AYDA). AYDA pada umumnya merupakan suatu asset dimana jaminan menurut Undang-Undang Perbankan dapat diperoleh dan dibeli sebagian atau seluruhnya dari asset tersebut.Baik melalui pelelangan maupun diluar pelelangan berdasarkan penyerahan secara sukarela oleh pemilik agunan tersebut. Apabila debitur tidak memenuhi kewajibannya kepada Bank, maka asset yang diambil alih kreditur ini wajib dicairkan secepatnya atau dalam kurun waktu 1 (satu) tahun. Pasal 1 Angka 15 Peraturan Bank Indonesia No. 7/2/PBI/2005 Tentang Penilaian Kualitas Aktiva Bank Umum memberi pengertian mengenai agunan yang diambil alih merupakan aktiva yang diperoleh Bank, baik melalui pelelangan maupun diluar pelelangan berdasarkan penyerahan secara sukarela oleh pemilik agunan atau berdasarkan kuasa untuk menjual di luar lelang dan pemilik agunan dalam hal debitur tidak memenuhi kewajibannya kepada Bank.

AYDA yang berupa tanah dan bangunan harus dilakukan apabila kredit tersebut sudah masuk dalam kategori kredit macet. Prakteknya pelaksanaan AYDA tersebut dilakukan 
dengan beberapa tahap dan melibatkan beberapa pihak, khususnya Bank dengan debitur dan/ atau pemilik hakatas tanah dan bangunan yang dijaminkan dalam memperoleh kredit dengan hak tangggungan tersebut yang diatur dalam Pasal 12a Undang-Undang No 7 Tahun 1992 sebagaimana telah diubah dengan Undang-Undang No 10 Tahun 1998 tentang Perbankan. AYDA digunakan sebagai salah satu perlindungan atas kredit macet yang dilakukan oleh debitur. Pada BPR Klaten, ketika menghadapi kredit macet. Kasus yang diambil oleh penulis adalah kasus Nasabah (debitur) yang melakukan pinjaman kredit pada tanggal 15 Juli 2015 dengan nilai pinjaman sebesar Rp. 400.000.000,- (empat ratus juta rupiah) dengan agunan yang dijaminkan berupa tanah dan bangunan dengan Sertifikat Hak Milik atas nama Nasabah (debitur) bernomor Sertifikat 01812 yang berlokasi di Joyotakan, Serengan, Surakarta.

Ketika telah jatuh tempo pembayaran dan pihak debitur Nasabah (debitur) belum melakukan pelunasan kredit, maka pihak BPR Klaten akan memberikan Surat Peringatan tertulis sebanyak tiga kali yang berisi kredit yang harus dibayar, bunga, dan tanggal jatuh tempo terakhir. Jika setelah Surat Peringatan diberikan dan belum ada pelunasan dari debitur, maka pihak BPR Klaten akan melakukan panggilan melalui telepon dan bagian kredit BPR Klaten akan mendatangi alamat rumah debitur. Kemudian dilakukan proses negosiasi dengan debitur sebelum dilakukannya proses penyelesaian secara litigasi melalui Pengadilan Negeri Klaten. Barulah ketika terjadi kesepakatan untuk menyerahkan agunan milik Nasabah (debitur) yang terletak di desa Joyotakan, Kecamatan Serengan, Kabupaten Surakarta sebagai jaminan kredit, BPR Klaten akan melakukan prosedur AYDA.

Pihak BPR Bank Klaten kemudian membuat Surat Pernyataan kepemilikan dan Surat Kuasa Jual secara Notarial antara calon pembeli Aset jaminan dan debitur atau pemilik jaminan. Isinya antara lain menyatakan bahwa jaminan berupa tanah dan bangunan milik debitur yang telah disetujui untuk dijaminkan tersebut bukan merupakan milik debitur tetapi merupakan milik Bank. Proses pembuatan dan penandatanganan surat dan akta pengambilalihan aset jaminan Nasabah (debitur) tersebut dilakukan bertempat di BPR Bank Klaten dan dihadapan Notaris, supaya terjadi keabsahan dalam penandatanganan pengambilalihan aset.

Tanah yang telah berganti kepemilikan pihak Bank melalui kuasa yang ditunjuk tersebut dapat dijual melalui proses tawar menawar maupun lelang untuk mengganti kerugian dari pihak kreditur. Jika tanah dan bangunan yang dijual oleh BPR Bank Klaten belum terjual sementara kredit yang diberikan pada debitur telah dilunasi, maka BPR Bank Klaten dapat melakukan penghapus bukuan perjanjian AYDA. Namun jika debitur telah melakukan pembayaran sebagian dan aset tersebut telah laku dijual untuk menutupi sebagian pembayaran kredit, maka uang sisa hasil penjualan akan dikembalikan pada debitur. Karena dari pihak debitur belum melakukan pembayaran setelah ditandatanganinya Surat Pernyataan dan Surat Kuasa Jual aset berupa tanah dan bangunan di Joyotakan, maka pada tanggal 23 Desember 2016 pihak BPR Bank Klaten membuat Berita Acara Komite Penyelesaian Kredit Tentang Persetujuan Pembukuan AYDA, dengan isi bahwa komite tersebut sepakat untuk mengambil alih aset tanah dan bangunan milik Nasabah (debitur) sebesar Rp. 800.000.000,- (delapan ratus juta rupiah). Kemudian pada tanggal yang sama diterbitkan juga Surat Keterangan No. PD.BPR.BK/01.4/1252/XII/2016, yang menyatakan bahwa kredit yang dipinjam debitur sebesar Rp. 413.000.000,- (empat ratus tiga belas juta) tersebut dinyatakan lunas. 
Dari kasus tersebut, kredit macet dengan debitur Nasabah (debitur) yang terjadi pada BPR Bank Klaten disebabkan oleh 2 faktor, yaitu faktor internal dan faktor eksternal. Faktor internal meliputi suatu kesalahan yang dibuat oleh pihak kreditur sendiri, yaitu:

1) Kurangnya informasi nasabah sebagai peminjam kredit.

Hal ini cenderung menjadi penyebab terjadinya kredit bermasalah karena informasi nasabah sangatlah penting, karena dengan adanya informasi nasabah yang lengkap makadapat memberi informasi secara jelas dimana debitur itu menetap, berasal dan bekerja. Dengan itu akan dapat meminimalisir nasabah yang mempunyai itikad yang tidak baik, seperti lari dari tanggung jawab.

2) Kurangnya ketelitian petugas lapangan dalam menganalisa kredit.

Hal ini menyebabkan beberapa nasabah menjadi kurang lancar dalam membayar angsuran mereka, dikarenakan nominal pembayaran pinjaman dengan penghasilan dari nasabah tersebut tidak sinkron. Hal ini disebabkan oleh besarnya pinjaman kredit \& jangka waktu yang kurang tepat untuk nasabah yang dapat dikatakan kurang mampu. Sehingga menyebabkan pembayaran kredit menjadi kurang lancar, apabila terus dibiarkan akan mengarah ke kredit yang bermasalah. Oleh karena itu, ketelitian petugas lapangan dalam menganalisa kredit sangatlah diperlukan.

3) Rendahnya kemampuan pihak Perbankan dalam melakukan analisis permohonan kredit. Analisis kredit merupakan hal yang penting dalam pemberian kredit, dimana calon nasabah peminjam kredit harus memberikan laporan keuangan dan dokumen-dokumen pendukung yang lengkap. Sehingga pihak BPR Bank Klaten bisa menentukan layak tidaknya calon nasabah tersebut untuk mendapatkan fasilitas kredit atau dengan menganalisa kredit pihak Bank dapat menurunkan nominal pinjaman pada kredit tersebut apabila data-data nasabah kurang dianggap akurat.

Sedangkan faktor eksternal atau faktor penyebab kredit macet dari debitur BPR Bank Klaten dalam kasus posisi tersebut yaitu:

1) Adanya kegagalan/musibah yang menimpa perusahaan/usaha nasabah sehingga membuat debitur menjadi rugi dan secara langsung berpengaruh terhadap pembayaran kredit yang sedang berlangsung karena apabila nasabah mengalami kegagalan/musibah menyebabkan pendapatan debitur menjadi berkurang yang disebabkan oleh tanggungan beban kerugian. Dalam hal ini, musibah yang menimpa debitur yaitu adanya bencana banjir yang membuat bisnis properti milik Nasabah (debitur) tidak laku, sehingga mempengaruhi kemampuan debitur untuk membayar.

2) Adanya itikad tidak baik dari pihak nasabah sehingga menyebabkan tidak lancarnya pembayaran kredit. Dalam pengawasannya, debitur ini sedang tidak terkena musibah maupun kegagalan apapun, namun diperkirakan memang dari itikad dari debitur itu sendiri yang sengaja melakukan hal seperti itu. Dalam kasus kredit macet di BPR Bank Klaten, itikad tidak baik terlihat dalam debitur yang sulit dihubungi sehingga menyulitkan petugas lapangan dalam melakukan penagihan kredit.

Pada implementasinya di lapangan, pelaksanaan AYDA di BPR Bank Klaten juga menghadapi beberapa kendala yang berhubungan dengan regulasi, antara lain:

1) Proses AYDA yang membutuhkan banyak persyaratan secara Notarial dan biaya dalam pembuatan berbagai akta dan pembayaran pajak, yang menyebabkan adanya defisit keuangan dari pihak BPR Bank Klaten; dan 
2) Penjualan aset jaminan yang disita dari debitur dalam proses AYDA membutuhkan waktu lama untuk dijual, sedangkan batas waktu yang ditentukan oleh Otoritas Jasa Keuangan hanyalah 1 (satu) Tahun, sehingga membuat adanya penurunan harga tanah debitur. Terbukti dari penjualan barang yang sudah mencapai jangka waktu 1 Tahun, namun tanah agunan belum terjual karena belum mencapai kesepakatan harga.

Untuk mengantisipasi kredit macet tersebut, pihak BPR Klaten melakukan prinsip 5C, 5P, dan 3R sebagai acuan analisis untuk menghadapi berbagai masalah kredit. Prinsip 5C yaitu Character (watak), Capacity (kemampuan), Capital (modal), Collateral (angunan) dan Condition of economic (prospek usaha debitur). Prinsip 5P yaitu Party (pihak), Purpose (tujuan), Payment (pembayaran), Profitability (keuntungan), dan Protection (perlindungan). Sedangkan Prinsip 3R, yaitu Returns (Hasil yang Diperoleh), Repayment (Pembayaran Kembali), Risk Bearing Ability (Kemampuan Menganggung Risiko).

Jika kredit macet telah terjadi, maka pihak BPR Klaten akan melakukan beberapa upaya untuk mengatasi kredit macet, yaitu Reschedulling (memperpanjang jangka waktu kredit) untuk memberikan tambahan waktu pada debitur untuk melakukan pelunasan, Reconditioning (persyaratan kembali) yaitu mengubah sayarat-syarat perjanjian kredit supaya lebih meringankan kreditur dan, Restructuring (penataan ulang), yaitu menambah modal nasabah dengan pertimbangan nasabah memang membutuhkan tambahan dana dan usaha yang dibiayai memang masih memiliki prospek yang baik.

Pengambilalihan barang jaminan merupakan jalan terkahir untuk menutup hutang yang dimiliki oleh nasabah, yang biasanya dilakukan melalui proses AYDA. Hal tersebut dikarenakan tidak ada jalan keluar lagi untuk menutup hutang yang dimiliki nasabah, sedangkan BPR Bank Klaten harus tetap menjaga stabilitas keuangan mereka dari tahun ke tahun agar tidak terjadinya penurunan kredibilitas dimata nasabah yang akan berdampak pada kebangkrutan. BPR Bank Klaten tidak menggunakan penyelesaian yang bersifat litigasi, karena pada dasarnya BPR Bank Klaten berasaskan asas kekeluargaan, sehingga BPR Bank Klaten dapat dikatakan sebagai usaha bersama,yang harus mencerminkan ketentuan-ketentuan seperti lazimnya dalam suatu kehidupan keluarga. Oleh karena itu, BPR Bank Klaten lebih memprioritaskan segala permasalahan harus diselesaikan dengan cara kekeluargaan.

\section{Simpulan}

AYDA sebagai perlindungan kreditur atas kredit macet yang terjadi pada BPR Klaten dilakukan supaya tidak terjadi penurunan kredibilitas dimata publik, untuk menjaga kesehatan Bank, dan untuk mengantisipasi adanya Surat Peringatan dari Otoritas Jasa Keuangan yang dapat berdampak pada kebangkrutan. Namun sebelum melakukan AYDA, pihak BPR Klaten melakukan berbagai upaya untuk mengahdapi kredit macet seperti pemberian Surat Peringatan sebanyak tiga kali, mendatangi alamat debitur untuk melakukan negosiasi terkait pembayaran kredit, dan berbagai penyelesaian lain yang berlandaskan asas kekeluargaan supaya menghindari penyelesaian melalui jalur litigasi. Walaupun pada prakteknya prosedur AYDA masih memiliki beberapa kendala terutama terkait banyaknya syarat Notarial dan pajak yang diperlukan, AYDA masih digunakan oleh pihak BPR Klaten untuk mengatasi kredit macet yang terjadi, supaya terjadi solusi yang tidak merugikan kedua belah pihak. 


\section{E. Saran}

Pihak BPR Bank Klaten perlu mempertegas perjanjian kredit dimaksudkan untuk menekan debitur yang lalai akan tanggungjawabnya sehingga kreditur dan debitur memiliki proses yang cepat dalam melakukan tindakan apabila terjadi kredit yang macet. pihak Perseroan Daerah BPR Bank Klaten dapat meningkatkan dan mempertahankan ketelitian dalam pengaplikasian Pasal 8 Ayat (1) Undang-Undang Nomor 10 Tahun 1998 tentang Perbankan dimana Bank umum wajib memiliki keyakinan analisis yang mendalam dalam pemilihan nasabah atau calon debitur. Prinsip 5C atau The Five $C$ of Credit Analysis yaitu character, capacity, capital, condition of economy, collateral mungkin penerapan tersebut harus dilakukan tidak hanya sekali untuk menentukan calon debitur layak atau tidaknya sehingga mencegah terjadinya kemungkinan kredit macet.

\section{F. Daftar Pustaka}

\section{Buku}

Hermansyah, SH., M.Hum. 2008. Hukum Perbankan Nasional Indonesia. Jakarta : Kencana

Jamal Wiwoho. 2011. Hukum Perbankan Indonesia. Surakarta : UNS Press

Philipus M. Hadjon. 1987. Perlindungan Hukum Bagi Rakyat Indonesia. Surabaya: PT. Bina Ilmu

Purwahid Patrik. 2005. Hukum Jaminan, Edisi Revisi Dengan UUHT. Semarang: Universitas Diponegoro Press.

Soerjono Soekanto. 2010. Pengantar Penelitian Hukum. Jakarta: Penerbit Universitas Indonesia (UI-Press).

\section{Jurnal}

Andika Persada Putera. 2013. "Penyelesaian Sengketa Perbankan Dengan Mediasi”. Jurnal Yuridika. Volume 28 No 1 Januari 2013. Surabaya: Fakultas Hukum Universitas Airlangga.

Tri Novidianto \& Tutiek Retnowati. 2018. "Perlindungan Hukum Bagi Kreditor Untuk Kredit Yang Diambil Alih (Take Over) Dengan Pelunasan Dan Jaminan Yang Dikeluarkan Tidak Pada Hari Yang Sama”. Jurnal Al'Adl. Volume 10 Nomor 1 Januari 2018. Surabaya: Universitas Narotama Surabaya.

Lukmanul Hakim. 2018. "The Alternative Model Settlement of Credit Problems in Banking Agencies”. Fiat Justisia Journal of Law. Volume 12 Number 2 April 2018. Bandarlampung: Universitas Lampung.

Olyvia Darussalam. 2013. "Faktor-Faktor Penyebab Kredit Bermasalah Di PT. Bank Sulut Cabang Utama Manado”. Jurnal EMBA. Volume 1 Nomor 4 Desember 2013. Manado: Universitas Sam Ratulangi. 
Bayu Rangga Warsito, Albertus Sentot Sudarwanto. Penyelesaian Kredit Macet dengan Agunan yang ...

\section{Peraturan Undang-Undang}

Kitab Undang-Undang Hukum Perdata

Undang-Undang Nomor 10 Tahun 1998 tentang Perbankan

Undang-Undang Nomor 21 Tahun 2011 tentang Otoritas Jasa Keuangan

Undang-Undang Nomor 23 Tahun 2014 tentang Pemerintahan Daerah

Undang-Undang Nomor 30 Tahun 1999 tentang Arbitrase Dan Alternatif Penyelesaian Sengketa

Peraturan Pemerintah Nomor 27/PMK.06/2016 tentang Petunjuk Pelaksanaan Lelang

Peraturan Bank Indonesia Nomor 14/15/PBI/2012 tentang Kualitas Penilaian Aktiva

Peraturan Daerah Klaten Nomor 6 Tahun 2010 tentang Bank Perkreditan Rakyat Klaten 